\title{
CARIAN: ON THE LUWIAN-GREEK INTERFACE
}

\begin{abstract}
In the present paper an attempt will be made to elucidate the contents of a selection of Carian inscriptions. To this aim, the values of the individual signs will be scrutinized against the backdrop of their origin in on the one hand the Phoenician alphabet and on the other hand the Cretan Linear and Cypriot Syllabic scripts. In so far possible, the results thus achieved will next be tested by evidence from structural analysis. Finally, it will be demonstrated on the basis of a selection of texts that the Carian language can be classified as a Luwian dialect heavily influenced by Greek. In the course of the latter demonstration it will also become clear that there can be distinguished at least three different categories among the texts selected, namely: (1) dedicatory, (2) public, and (3) funereal ones.
\end{abstract}

\section{Introduction}

We owe it to the merit of Ignacio Adiego that there is a state-ofthe-art publication on Carian, in which all the Carian inscriptions available to the author at the time this edition appeared (2007) are assembled and presented with a drawing. In this book, the Carian inscriptions are transliterated according to the "Ray-Schürr-Adiego System", which is proclaimed to be "commonly accepted" and to offer a "definitive decipherment" of the Carian language. However, commonly accepted or not, there are some serious drawbacks to this decipherment. In the first place, the only evidence that pops up consists of onomastics. This category of evidence is from a linguistic point of view rather weak. The criterium for a decipherment is that it reveals a sentence, with a subject, object, and verb all marked as such by distinctive features. From this point of view, only the attempt at elucidation of a Carian inscription (C.xx 1) according to the "Ray-Schürr-Adiego System" by Craig Melchert in 1993 should come into consideration. ${ }^{1}$ However, and this is our second point, the system of transliteration happens to be basically flawed. As one of the critics, Roberto Gusmani, pointed out the letters of the alphabet are considered to express values entirely different from the common ones and as such supposed to be subject of

${ }^{1}$ Melchert, Some remarks; Adiego, The Carian Language, 201; 281-282. 
"metakharakterismós". ${ }^{2}$ Thus gamma is supposed to render the value of delta, delta that of lambda, lambda that of beta, etc. This is not how the alphabet works: even in the most extreme case of tampering with it known up to date, that of the Southwest Iberian script, the 14 signs of the alphabet represent their conventional value and are enumerated in their conventional order in the abecedarium discovered on a stone slab from Espanca. ${ }^{3}$ The alphabet, namely, is not only a script, but also a mnemonic device. Accordingly, although it is true that in isolated cases an alphabetic sign may be used for the expression of secondary value, in the main it should apply that each alphabetic sign represents its traditional value.

\section{The Signary}

To a decipherment, therefore, it is of key importance to trace the origin of a sign in order to determine its value. Now, in the Carian script there can be distinguished two categories of signs as far as their origin is concerned, namely: (1) those originating from the Phoenician alphabet, and (2) others originating from the Cretan Linear (= CL) or related Cypriote Syllabic (=CS) script.

To the first category may, at least in my opinion, be assigned 21 individual signs (see Fig. 1). It is of relevance to note that some of these signs may occur in 90 or 180 degrees turned position, like alpha, epsilon, lambda, and samek. ${ }^{4}$ Moreover, rounded signs may occur in angular writing variant, as in case omicron and qoppa, and angular ones in rounded writing variant, as in case of gamma and delta. Like in the Phrygian, Lydian, and Greek alphabets, an old variant of wau is used for the expression of upsilon. The Carian alphabet further shares with its Lydian and Greek counterparts the development of Phoenician tsade into san, which latter should be distinguished from the late form of $m u$. Of the odd writing variants, the hour-glass form of samek is paralleled for the alphabet of Knidos ${ }^{5}$ and the 180 degrees turned and roundish variant of $p i$ corresponds to its equivalent in the Southwest Iberian Espanca alphabet. ${ }^{6}$ A typical feature of the Carian alphabet, rightly analyzed as such by John Ray, is the open-worked variant of rho, which in the past has been wronly taken for the wau. ${ }^{7}$ Yet another typical feature of the Carian alphabet, rightly analyzed by Ray, is the use of the circle with a vertical or horizontal crossbar inside for the expression of the value $s .{ }^{8}$ I have placed this sign in my Fig. 1 in the

\footnotetext{
${ }^{2}$ Adiego, The Carian Language, 201.

${ }^{3}$ Cf. de Hoz, The Phoenician Origin, 674; 681-682.

${ }^{4}$ Cf. Woudhuizen, Etruscan Origins, 108, Fig. 12.

${ }^{5}$ Jeffery, The Local Scripts, Table of Letters; cf. Woudhuizen, Lydian, 101, Fig. 3.

${ }^{6}$ See note 3.

${ }^{7}$ Adiego, The Carian Language, 193 (fig.); 194 (table).

${ }^{8}$ Adiego, The Carian Language, 195 and our note 7.
} 
position of Greek psi because to all probability it originates from the bigraph of phi and sigma for the expression of this typically Greek value - the Carians, while dropping the sigma, using the residual phi for their primary sibilant. If this analysis applies, phi is definitly used for a secondary value. The latter verdict, finally, also applies to qoppa and $k h i$, which are used for the expression of the secondary values $i$ and $\tilde{e}$, respectively. The use of $k h i$ for $\tilde{e}$ Carian shares with Lydian. ${ }^{9}$ It is of relevance to note that these two signs can be used for the expression of both their original and secondary values in one and the same inscription, as in case of, for example, E.Sa 1 from Saqqara in Egypt (see discussion below).

The use of signs originating from the Cretan Linear or Cypriot Syllabic script Carian shares with the other Anatolian alphabets, like Lydian, Lycian, and Sidetic. ${ }^{10}$ To this particular category of auxiliary signs can be assigned seven individual graphs (see Fig. 2).

In the case of consonants, the original syllabic value is reduced by the dropping of the vowel according to the acrophonic principle. The only exception is formed by syllabic re, which is used for a secondary value, $\tilde{n}$. By and large, the closest parallels for the Carian signs in question can be traced in the Eteo-Cyprian variant of the Cypriot syllabary. ${ }^{11}$ Only in the case of Carian $j$ the origin has to be traced directly to Cretan Linear je, no descendant of it being attested for any of the variants of the Cypriot syllabary. ${ }^{12}$

The fact that the Carian alphabet, or the Anatolian ones more in general, are characterized by complementary signs from another, non-Phoenician script, is not exceptional, but paralleled for a.o. the Coptic alphabet in Egypt with its 7 supplementary signs from Demotic.

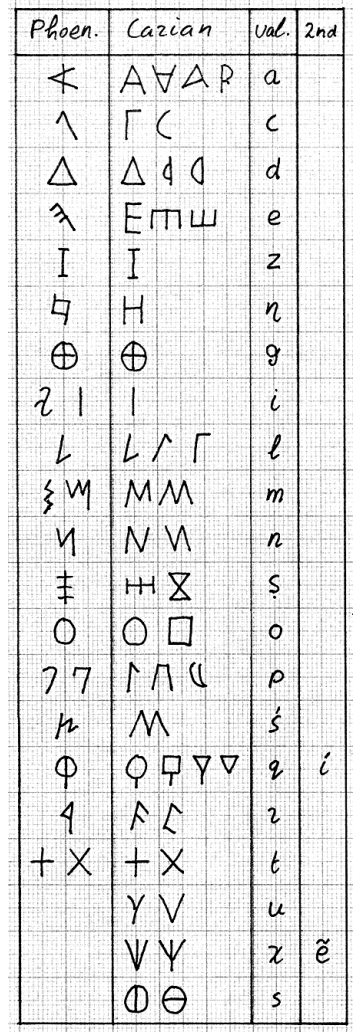

Fig. 1. Carian signs originating from the Phoenician alphabet

${ }^{9}$ Gusmani, Lydisches Wörterbuch, 29; cf. Woudhuizen, Lydian, 102, Fig. 4.

${ }^{10}$ Woudhuizen, The Transmission, 180, Fig. 5 (Lydian); Woudhuizen, Origins of the Sidetic Script, 126, Fig. 13; note furthermore that the Lycian double-axe sign for $\tilde{e}$ originates from the Cretan Linear double-axe sign (LA 52) for $a$.

${ }^{11}$ Masson, Les inscriptions cypriotes, 63, Fig. 4.

${ }^{12}$ Ventris \& Chadwick, Documents, 23, Fig. 4. 


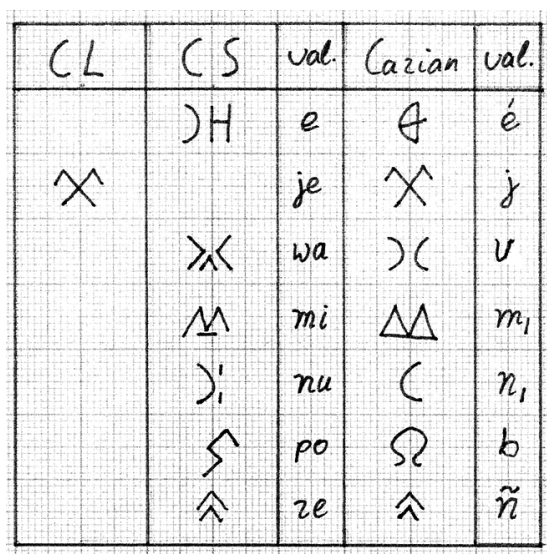

Fig. 2. Carian signs originating from the Cretan Linear and Cypriot Syllabic scripts

\section{Structural features}

The Carian inscriptions most liable to a structural analysis are all of funerary nature and mostly come from Egypt, particularly from Memphis. These inscriptions largely consist of personal names, but sometimes bear testimony of some additional repetitive elements.

The identification of the Carian phi-sign as its foremost sibilant by Ray enables us to deduce from its frequent occurrence in final position of a combination that it serves to indicate the ending of the genitive singular in $-s .{ }^{13}$ This ending is formally related to the Luwian hieroglyphic genitive singular in $-s a$ and the Lycian one in $-h\left(<*_{-} s\right)$, and ultimately originates from Proto-Indo-European (= PIE) $*_{-}(o) s .{ }^{14}$

Another recurrent feature is the enclitic conjunction -té "and", which appears as much as 55 times in the funereal texts from Egypt. It originates from PIE $*-k^{w} e$ and shows the labiovelar development $* k^{w}>$ $t$ also traceable in Lycian (relative pronoun $t i-<* k^{w} i$-) and, more to the point in this connection, in Greek (conjunction $\tau \varepsilon<*-k^{w} e$ ).

Yet another recurrent element in the funeral inscriptions consists of a combination of four letters identified by Piero Meriggi as the Carian word for "son". ${ }^{15}$ In our transliteration this reads (with the secondary value $\tilde{e}$ for the $k h i$-sign) nẽos or, in variant writing with the Greek san as attested for an inscriptions from Kaunos (C.Ka 5, 1. 17), ne$o s$. This occurs 11 times in sum and can not be dissociated from Greek véoৎ "young" < PIE *néwos "new" 16 (the Luwian hieroglyphic word for "son" reads $n a(w a)-)$.

Next, there is a repetitive element which occurs as much as 15 times in various writing variants as $u m_{1} a, u m_{1} e, u m_{1} o$, and $e m_{1} O$ as well as in abbreviation as $u o$. This clearly confronts us with the Carian reflex of the Luwian hieroglyphic pronoun of the 1st person singular, amu "I, me", also of PIE antecedents ( ${ }^{\prime} h_{1} m e$ "me"). ${ }^{18}$ It transforms the inscriptions in question in so-called "redende Inschriften" which are such a characteristic feature of the archaic period, not only in Greek

\footnotetext{
${ }^{13}$ Adiego, The Carian Language, 268.

${ }^{14}$ Woudhuizen, Selected Luwian Hieroglyphic Texts, 136 and 313; 432; 404.

${ }^{15}$ Adiego, The Carian Language, 187.

${ }^{16}$ Mallory \& Adams, The Oxford Introduction, 300; 303.

${ }^{17}$ Woudhuizen, Selected Luwian Hieroglyphic Texts, 346 and 348.

${ }^{18}$ Woudhuizen, Selected Luwian Hieroglyphic Texts, 320; 404.
} 
( $\mu^{\prime} \varepsilon \pi \mathrm{o} \varepsilon \sigma \varepsilon$ "he made me", $\mu^{\prime} \alpha \nu \varepsilon \theta \varepsilon \kappa \varepsilon$ "he dedicated me") but also in Lydian $^{19}$ and, up to the Classical period, in Sidetic. ${ }^{20}$

Finally, one of the names in the Carian funeral inscriptions in Memphis happens to be exceptionally popular as it occurs as much as 15 times in sum, mostly in form of necoẽs, but once also as neqoẽs. Apparently, therefore, Carian inhabitants of Memphis named themselves after one of their benefactors, the Egyptian pharaoh Nekho II $(610-595 \mathrm{BC}){ }^{21}$

\section{Selected inscriptions}

\subsection{Dedicatory}

\section{C.xx 2 bronze dinos of uncertain origin ${ }^{22}$}

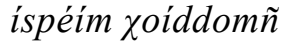

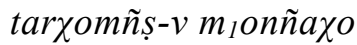

"His libation-vessel,

Tarkhomnos has made (it)."

\section{Comments} continua.

The text runs in left-to-right direction of writing, in scriptio

ispéim: $\mathrm{A}(\mathrm{m} / \mathrm{f}) \mathrm{sg}$. in - $m$ of ispéi-, the possessive pronoun of the 3rd person, corresponding to Lycian ehbi- "his". ${ }^{23}$ The A sg. ending in $-m$, an archaic Indo-European feature, is paralleled for the exceptional case of Lycian term) in TL $84, \S 8 .{ }^{24}$ Note that this form of the pronoun refers to the deity to whom the dinos is dedicated.

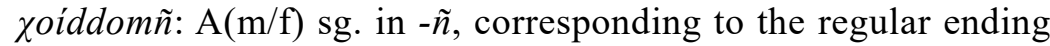
for this case in IE Anatolian as represented by Luwian hieroglyphic -na, Lycian $-\tilde{n}$, and Lydian $-n,{ }^{25}$ of the noun $\chi o i d d o m-$ which indicates the dedicated object and of which the first element $\chi o i$ - is related to Greek

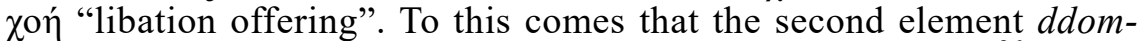
presumably confronts us with a reflex of PIE * déh ${ }_{3} r / n$ - "gift". ${ }^{26}$ At any rate, the dinos undoubtedly served as a libation-vessel.

tarzomñs: $\mathrm{N}(\mathrm{m} / \mathrm{f}) \mathrm{sg}$. in $-s$, corresponding to Luwian hieroglyphic $-s a$, Lycian $-s$, and Lydian $-s$ or $-s$ for the same function, ${ }^{27}$ of the MN

19 Woudhuizen, Two Notes on Lydian, 207-209 (Lyd. no. 30: Titis-in ẽmi ti-Sardi $_{1}$ fabil "Titis has dedicated me at Sardis").

${ }^{20}$ Woudhuizen, Origins of the Sidetic Script, 121 (Sid. no. 1: $m_{1} i$ AӨana "I (am) for Athena").

${ }^{21}$ Herodotos, Histories II, 158-159; IV, 42. Cf. Egyptian hieroglyphic Nk3w, Greek

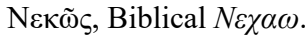

${ }^{22}$ See esp. Gusmani, Zwei neue Gefässinschriften, Tafels II-IV; Adiego, The Carian Language, 161.

${ }^{23}$ Melchert, A Dictionary, 12-13.

${ }^{24}$ Melchert, A Dictionary, 63; Woudhuizen, Lycian Forms, 422 and 424.

${ }^{25}$ Woudhuizen, Selected Luwian Hieroglyphic Texts, 431.

${ }^{26}$ Mallory \& Adams, The Oxford Introduction, 273-274.

${ }^{27}$ Woudhuizen, Selected Luwian Hieroglyphic Texts, 431. 


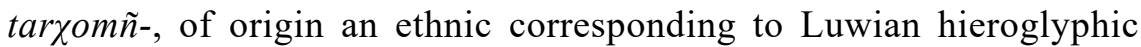
Tarhu(nt)-umina- "Tarkhunt town", the exact writing of the Hittite province Tarhuntassa. The divine name Tarhu(nt)- denotes the Luwian storm-god, whose name can be traced back to PIE *terh $2^{-}$"to overcome, be victorious". ${ }^{28}$ Note that the rendering of the PIE laryngeal $* h_{2}$ by a guttural is typical for the IE Anatolian languages and agrees with the information from the glosses according to which the Carian reflex of PIE * $h_{2}$ ówi- "sheep" is Koĩov. ${ }^{29}$

$-v$ : sentence introductory particle, related to Luwian hieroglyphic $w a$ - or $-w a$ and Lycian -we for the same function. ${ }^{30}$

$m_{1}$ onña 0 : 3 rd person sg. of the past tense in $-\chi o$ of the verb $m_{1}$ onña-, the root of which is related to that of Hittite maniyah- "to handle". ${ }^{31}$ Note that from a comparative point of view the ending $-\chi o$ is related to Greek $-\kappa \varepsilon$, the 3rd person sg. of the kappa-aorist of perfect. It has been suggested by Gusmani that the kappa in this Greek ending originates from PIE laryngeal $* h_{2}{ }^{32}$ If rightly so, the kappa-aorist and perfect can be attributed to IE Anatolian influence on Greek, as only in IE Anatolian PIE $* h_{2}$ is represented by a guttural.

\section{C.xx 1 bronze phiale of uncertain origin ${ }^{33}$}

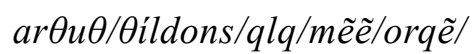

eqro/misn $n_{1} a$
"Arthuth, (the son) of Thildons has dedicated the kylix as a thank-offering to the great God."

\section{Comments}

The inscription runs in retrograde direction of writing. The individual elements are distinguished as such by a punctuation mark in the form of a vertical bar, transliterated as /.

$\operatorname{ar} \theta u \theta$ : endingless $\mathrm{N}(\mathrm{m} / \mathrm{f}) \mathrm{sg}$. of the $\mathrm{MN} \operatorname{ar} \theta u \theta-$, no doubt a reflex of Luwian hieroglyphic Arawata- "Arnuwandas". ${ }^{34}$ Note that the endingless $\mathrm{N}(\mathrm{m} / \mathrm{f}) \mathrm{sg}$. is paralleled for Lycian. ${ }^{35}$

Gildons: G sg. in -s of the patronymic fildon-, for which parallels to the best of my knowledge are lacking.

\footnotetext{
${ }^{28}$ Woudhuizen, Selected Luwian Hieroglyphic Texts, 402.

${ }^{29}$ Adiego, The Carian Language, 8; 10; for the PIE root, see Mallory \& Adams, The Oxford Introduction, 112.

${ }^{30}$ Woudhuizen, Selected Luwian Hieroglyphic Texts, 146 and 369; 430.

${ }^{31}$ Friedrich, Kurzgefaßtes Hethitisches Wörterbuch, s.v.

${ }^{32}$ Gusmani, Isoglossi, 511 (compares the 1st person sg. Greek - $\kappa \alpha$ to Luwian -ha, which originates from PIE *-h2e, see Beekes, Vergelijkende Taalwetenschap, 283).

33 See esp. Gusmani, Zwei neue Gefässinschriften, Tafels I-II; Adiego, The Carian Language, 160.

${ }^{34}$ Woudhuizen, Selected Luwian Hieroglyphic Texts, 323.

${ }^{35}$ Melchert, A Dictionary, x; Houwink ten Cate, The Luwian Population Groups, 5354, esp. 55.
} 
$q l q$ : endingless $\mathrm{A}(\mathrm{m} / \mathrm{f}$ or $\mathrm{n}) \mathrm{sg}$. of a vase-name corresponding to

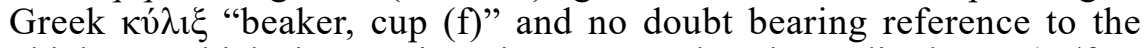
phiale on which the text is written. Note that the endingless $A(m / f$ or n) sg. is paralleled for Lycian. ${ }^{36}$

mẽẽ: abbreviation of Luwian hieroglyphic maluwa- "thank-offering" in its typical Cyprian variant writing me-e-lu-we as attested for a Linear C inscription on a weight from Enkomi, dated to $c .1600 \mathrm{BC} .^{37}$

orqẽ : 3rd person sg. of the past tense in $-q \tilde{e}$ of the verb or- no doubt expressing the meaning "to dedicate". The verbal root may well be a reflex of PIE * $h_{3} e r$ - "set in motion (vertically)". ${ }^{38}$ At any rate, such a view is in keeping with the fact that the object was literally raised in the act of offering. Note furthermore that the ending in $-q \tilde{e}$ confronts us with a graphic variant of $-\chi o$ as attested for the previous inscription, which closer resembles the ending of the $3 \mathrm{rd}$ person sg. of the kappa-aorist or perfect in Greek, $-\kappa \varepsilon$.

eqqro: endingless $\mathrm{D}$ sg. (or do we rather have to assume here a iota subscriptum?) of the adjective eqro- "great", which is no doubt

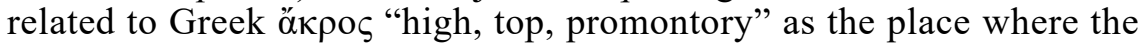
god is situated. If so, it follows that eqqro- can be traced back to PIE *akri- or *akro- "high, top" and that Carian, just like Luwian, belongs to the centum-group among the Indo-European languages. ${ }^{39}$

$m_{1 s ̦} n_{1} a$ : D sg. in $-a$, corresponding to Luwian hieroglyphic $-a$ and Lycian - $a$ for the same function, ${ }^{40}$ of the noun $m_{1} s n_{1}(a)$ - "god", the root of which is characterized by syncope but nevertheless obviously corresponds to Luwian hieroglyphic masana- and Lycian mahana- of the same meaning. ${ }^{41}$

\section{C.Ia 3 cratera from Iasos}

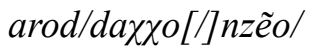

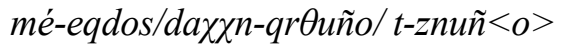

"Herodes has dedicated to the Nyseian (god)."

Egidos (has) take(n) care of me and prepare(d me) as a dedication."

${ }^{36}$ Melchert, A Dictionary, x; cf. Houwink ten Cate, The Luwian Population Groups, 53-54, esp. 55.

37 Woudhuizen, Selected Luwian Hieroglyphic Texts, 141; Woudhuizen, The Language of the Sea Peoples, 147-148.

${ }^{38}$ Mallory \& Adams, The Oxford Introduction, 391.

${ }^{39}$ Woudhuizen, Selected Luwian Hieroglyphic Texts, 399; 407-409.

${ }^{40}$ Woudhuizen, Selected Luwian Hieroglyphic Texts, 432.

${ }^{41}$ Woudhuizen, Selected Luwian Hieroglyphic Texts, 427. 


\section{Comments}

The inscription runs in left-to-right direction of writing, and the individual elements are distinguished as such by a punctuation mark in the form of a vertical bar, transliterated as /. The final letter $n$ of da $\chi \chi n$ is omitted by Adiego in his drawing of the text and mistaken by him in his transliteration for a punctuation mark. ${ }^{42}$ However, this sign is clearly present in the drawing by Gusmani. ${ }^{43}$

arod: endingless $\mathrm{N}(\mathrm{m} / \mathrm{f}) \mathrm{sg}$. of the $\mathrm{MN}$ arod-, corresponding to Greek ${ }^{\prime} \mathrm{H} \rho \omega \delta \eta$ s.

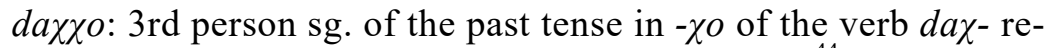
calling Phrygian $d a$ - or da $\chi$ - "to place, put; to dedicate" 44 and therefore in like manner originating from PIE $* d^{h} e h_{1^{-}}$"to put". 45

nzẽo: endingless $\mathrm{D}$ sg. (or do we rather have to assume here a iota subscriptum?) of the adjective nzẽo- corresponding to Greek Nvбaĩos "Nyseian", no doubt referring to the god Dionysos here. In any case, the place-name Nv̄ $\sigma \alpha$ is recorded for Caria by Stephanos Byzantinos, Ethnica, s.v. Nusai.

mé: A of the personal pronoun of the 1st person singular. Note that this form is not Luwian, but Greek $(\mu \varepsilon)$. Like $u m_{1} a$, etc. "I, me" in the Egyptian funerary inscriptions (see section 3 above and section 4.3 below), the use of this pronoun turns the present text into a member of the class of "redende Inschriften".

eqdos: $\mathrm{N}(\mathrm{m} / \mathrm{f}) \mathrm{sg}$. in $-s$ of the MN eqdo-, likely to be considered

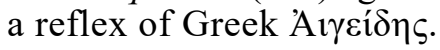

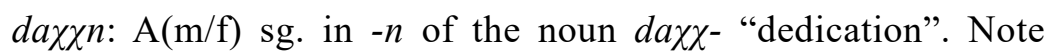
that the meaning of this noun is assured owing to the fact that it is based on the same root as the verb da - "to dedicate" (see above).

qr$\theta u \tilde{n} o$ : infinitive in -uño of the verb $q r \theta$ - "to mind, take care". The ending of the infinitive corresponds to Luwian hieroglyphic -una for the same function, ${ }^{46}$ whereas the verbal root in question is paralleled in Luwian hieroglyphic by harta- "to have a heart, mind". ${ }^{47}$ Now, the latter root confronts us with a reflex of PIE *kérd- "heart", ${ }^{48}$ from which it follows that, as we have already noted in connection with eqro- "great" (see discussion of C.xx 1 above) Carian, like Luwian, belongs to the centum-group among the Indo-European languages.

${ }^{42}$ Adiego, The Carian Language, 147-148; 286.

${ }^{43}$ Gusmani, Karische Beiträge, 146 (same form as 10th sign [count exclusive punctuation mark]).

${ }^{44}$ Waanders \& Woudhuizen, Phrygian \& Greek, 184.

${ }^{45}$ Mallory \& Adams, The Oxford Introduction, 295.

${ }^{46}$ Woudhuizen, Selected Luwian Hieroglyphic Texts, 315.

${ }^{47}$ Woudhuizen, Selected Luwian Hieroglyphic Texts, 332.

${ }^{48}$ Mallory \& Adams, The Oxford Introduction, 185 and 187; cf. Woudhuizen, Selected Luwian Hieroglyphic Texts, 400. 
$t$-: abbreviated form of the conjunction té "and", which in enclitic variant we have already come across in section 3 above.

$z n u \tilde{n}<o>$ : infinitive in $-u \tilde{n}<o>$ of the verb $z n$-, the meaning of which can be retrieved from oblivion by its correspondence to Hittite zinna- "to finish, complete". 49

\section{E.xx 7 on the base of a bronze lion, dated c. $500 \mathrm{BC}^{50}$}

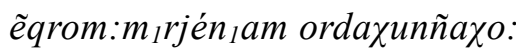

uqmé erns

\author{
"Ukhkhamuwas, (the son) of \\ Arn(th), has erected the great \\ Young Warrior."
}

\section{Comments}

The inscription runs in retrograde direction of writing. The individual units are distinguished as such by punctuation in form of two dots in columnar arrangement (:). Although the second letter is identified by Olivier Masson as omicron, ${ }^{51}$ Adiego rightly takes it for $q o p h .{ }^{52}$

eqqrom: $\mathrm{A}(\mathrm{m} / \mathrm{f}) \mathrm{sg}$. in $-m$ of the adjective éqro- "great" (see discussion of C.xx 1 above).

$m_{1} r j e ́ n_{1} a m: \mathrm{A}(\mathrm{m} / \mathrm{f}) \mathrm{sg}$. in - $m$ of the noun $m_{1}$ rjén ${ }_{1} a-$ "young warrior". Note that the root of the noun recalls Indo-Aryan márya- $(<\mathrm{PIE}$ méryos "young man") ${ }^{53}$ as an indication of charioteers. No doubt, the dedicated lion represented a divine representative of such a warrior.

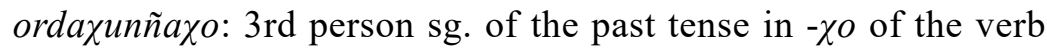
ordaұunña- which obviously renders the meaning "to dedicate" or "to set up, erect". In the first case one might consider a compound of orwith dax- (see discussion of C.xx 1 and C.Ia 3 above), in the second case perhaps rather one with first element orda-corresponding to Greek ỏ $\theta$ ó $\varsigma$ "straight, upright" $\left(<\mathrm{PIE} * w_{r e d}{ }^{h}\right.$ " to grow, stand, take shape"). ${ }^{54}$

uqmé: endingless $\mathrm{N}(\mathrm{m} / \mathrm{f}) \mathrm{sg}$. of the MN uqmé-, clearly a reflex of the Arzawan personal name Uhhamuwa- (with west-Luwian uhhafor regular huhha- "grandfather"). ${ }^{55}$

erns: G sg. in -s of the MN ern-, which likely comes into consideration as a shorthand writing variant of Luwian Arnuwandas.

${ }^{49}$ Friedrich, Kurzgefaßtes Hethitisches Wörterbuch, s.v.

${ }^{50}$ For the dating, see Adiego, The Carian Language, 31.

${ }^{51}$ Masson, Un lion de bronze, Pl. 2.

${ }^{52}$ Adiego, The Carian Language, 128.

${ }^{53}$ Mallory \& Adams, The Oxford Introduction, 204-205.

${ }^{54}$ Mallory \& Adams, The Oxford Introduction, 189-190.

55 Yakubovich, Sociolinguistics, 91; cf. Woudhuizen, Selected Luwian Hieroglyphic Texts, 413, note 36 . 
C.Ha 1 bronze phiale from Halikarnassos (6th century BC) ${ }^{56}$

$m n \tilde{n}$-ílrm/ $m_{1}(i)-m e \tilde{z o} /$ nñ-oriéqqẽ $/ m \tilde{e} e \tilde{e}$
"Manes (of) Hyllarima: me to the god." "He has dedicated it as a thank-offering."

\section{Comments}

According to the dealer, this phiale was discovered in Caria, in the region of Bodrum. The inscription runs in retrograde direction of writing, and the individual units are distinguished by a punctuation mark in the form of a vertical stroke (/).

$m n \tilde{n}$ : endingless $\mathrm{N}(\mathrm{m} / \mathrm{f}) \mathrm{sg}$. of $\mathrm{MN} m n \tilde{n}$-, likely to be taken for a reflex of Lydian Manes. ${ }^{5}$

ilrm: endingless $\mathrm{N}(\mathrm{m} / \mathrm{f}) \mathrm{sg}$. of the place-name ilrm-, correspon-

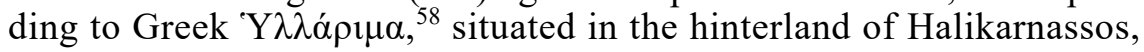
west of lake to the north of Kaunos.

$m_{l}(i): \mathrm{A}(\mathrm{m} / \mathrm{f})$ of the personal pronoun of the 1 st person singular. This form is most closely paralleled by Sidetic $m_{1} i$ "I" as referred to in note 20 above. Like in case of Lydian $\tilde{e} m i_{l}$ "me" (referred to in note 19 above), we are actually dealing here with forms of the Luwian hieroglyphic possessive pronoun (a)mi- "my" 59 which are secondarily used for the expression of the personal pronoun. At any rate, it turns the inscription into a member of the class of "redende Inschriften".

mẽzo: endingless D sg. (or do we rather have to assume here a iota subscriptum?) of the noun mẽzo- "god". This noun confronts us with a shorthand writing variant of $m_{1} s n_{1} a$ - in like manner as in Lycian maha- appears alongside mahana- ${ }^{6 \dot{0}}$

$n \tilde{n}: \mathrm{A}(\mathrm{m} / \mathrm{f}) \mathrm{sg}$. of the enclitic pronoun of the 3 rd person, corresponding to Lycian - $\tilde{n} n$ "him". ${ }^{61}$

oriẽqqẽ: 3rd person sg. of the past tense in -qqẽ of the verb oriée-. It seems likely that this verbal form is a more elaborate variant of orq $\tilde{e}$ as encountered in C.xx 1 above.

mẽe: abbreviation of Luwian hieroglyphic maluwa- "thank-offering" which we already came across in C.xx 1 (see discussion above).

56 Jucker \& Meier-Brügger, Ein Bronzephiale, 104-115; Adiego, The Carian Language, 144.

${ }^{57}$ Gusmani, Lydisches Wörterbuch, 163.

${ }^{58}$ Adiego, The Carian Language, 513.

${ }^{59}$ Woudhuizen, Selected Luwian Hieroglyphic Texts, 137; 141; and 320; 344.

${ }^{60}$ Melchert, A Dictionary, 36.

${ }^{61}$ Woudhuizen, Lycian Forms, 430 and 432. 


\section{C.Kr 1 stele from Krya (gulf of Telmessos) ${ }^{62}$}

$\theta o b o<l o>$ nu mñéma mẽsa oñucrs mc nẽos iẽorẽ-orédanm
"(This) monument for the god Apollo, Anaksagoras, the son of Magos, (has erected) as a sacred votive-stele."

\section{Comments}

The inscription runs in left-to-right direction of writing and no use is made of punctuation.

$\theta o b o<l o>n u$ : in my opinion this entity expresses the name of the god to whom the stele is dedicated, and, if so, the given emendation seems to suggest itself. At any rate, $\theta o b o<l o>n u$ may be argued to function as a (it must be admitted distorted) reflex of Greek $\tau$ o $\pi \mathrm{o} \lambda \lambda \mathrm{ov \imath}$ or $\tau \mathrm{o}$ $\mathrm{A} \pi \mathrm{o} \lambda \lambda \mathrm{ovi}$.

mñéma: endingless $\mathrm{A}(\mathrm{m} / \mathrm{f}) \mathrm{sg}$. of the noun mñéma- "stele", which is a patent loan from Greek $\tau$ ó $\mu v \tilde{\eta} \mu \alpha$ "memorial, memory".

mẽsa: D sg. in $-a$, corresponding to Luwian hieroglyphic $-a$ and Lycian - $a$ for the same function, of the noun messa- "god". We are already familiar with this form in its writing variant mẽzo from C.Ha 1 (see discussion above).

oñucrs: $\mathrm{N}(\mathrm{m} / \mathrm{f})$ in $-s$ of the $\mathrm{MN}$ oñucr-, which arguably comes into consideration as a shorthand of Greek Ava $\xi_{\alpha \gamma o ́} \rho \alpha \varsigma$.

$m c$ : endingless form of the MN $m c$-, corresponding to Greek Máyoc. In view of its association with the following nẽos "son" (see section 3 above), this $\mathrm{MN}$ functions as a patronymic and should have rendered the $\mathrm{G} \mathrm{sg}$. in $-s$.

iéorẽ-orédanm: $\mathrm{A}(\mathrm{m} / \mathrm{f}) \mathrm{sg}$. in $-m$ of a compound specifying the nature of the monument mñéma-. Now, the first element that appears to be distinguishable is iẽorẽ-, which bears a striking resemblance to

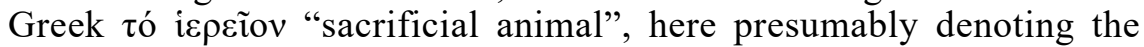
sacred nature of the object. The remainder, orédan-, may well be composed of the two roots, oré- and dan-, which we already came across in form of or- "to set up, dedicate" (C.xx 1) and ddom- "gift, offering". In sum, this would lead to a sacred-set up-offering, translated here as "sacred votive-stele".

\subsection{Public}

\section{G 1 stele from Athens, dated c. 525/520 $\mathrm{BC}^{63}$}

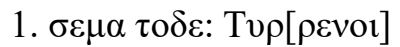

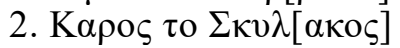

"This memorial (on behalf of) the Tyrrhenians, Karos from Skylake (has erected)."

${ }^{62}$ Adiego, The Carian Language, 158-159.

${ }^{63}$ Masson, Notes, 87-94; Adiego, The Carian Language, 164. 


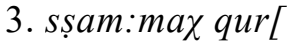
"(This) memorial, the assembly (of) the Tyrrhenians (has erected)."

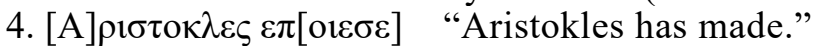

\section{Comments}

The bilingual inscription runs in left-to-right direction of writing and uses two dots in columnar (:) arrangement as punctuation mark. The Carian part of the text is confined to line 3 and, for being shorter than the Greek one, must be assumed to summarize the latter.

ssam: endingless A(n) sg. of the noun sșam- "memorial". This indication of the object corresponds exactly to the one used in Greek,

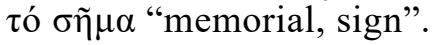

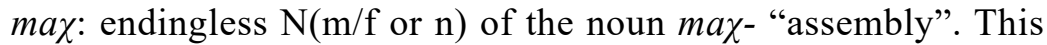
noun is a reflex of proto-Luwian *mekki- "numerous", originating from PIE *megh $h_{a^{-}}$"large, many", ${ }^{64}$ which functions as the counterpart of Hittite panku "assembly" ${ }^{65}$ As it seems, therefore, contrary to the Greek part of the text in the Carian part the subject is not expressed by the name of an individual person, Karos of Skylake, but by the organization he represents, the assembly. Now, it so happens that in Luwian the voiced velar * $\hat{g}$ is regularly lost, as exemplified in this particular case by Lycian miñt(i)- "council" ${ }^{66}$ From the case of the Carian epithet of Hermes, "I $\mu \beta \rho \alpha \mu \mathrm{\varsigma}$ "of the open field, wilderness" and related forms, originating from PIE $* \hat{g}^{h}$ eim- "winter, snow", ${ }^{67}$ it might at first sight be deduced that Carian shares this phonetic development with Luwian, but also for the related Lydian language the evidence is contradictory on this point, showing instances of preservation of the voiced velar alongside those of its loss. ${ }^{68}$ In view of $m a \chi-$, then, which shows preservation of the voiced velar, the Carian evidence on the topic may be as complicated as the Lydian one.

qur [: with a view to the Greek part of the text, it is clear that with this unfortunately partly preserved form, which specifies max"assembly", reference is made to the Tyrrhenians. In this connection, it is relevant to note that Lycian bears the testimony of a $c / t$-change, as in case of the MN Trzzubi of TL 111, which occurs in variant form Crzzubi in TL 83. In this connection it also deserves our attention that

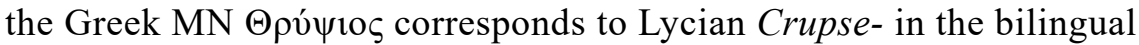
Lycian inscription TL 25. In like manner, then, qur [ may be explained as a variant writing of the expected tur [.

\footnotetext{
${ }^{64}$ Mallory \& Adams, The Oxford Introduction, 317 and 319.

${ }^{65}$ Bryce, The Kingdom of the Hittites, 109-111.

${ }^{66}$ Melchert, A Dictionary, 39.

${ }^{67}$ Mallory \& Adams, The Oxford Introduction, 300 and 302.

${ }^{68}$ Woudhuizen, Selected Luwian Hieroglyphic Texts, 411.
} 


\subsection{Funereal}

\section{C.Ka 1 funerary stele from Kaunos ${ }^{69}$}

miém:mñémam:mimusoฑs

nads:nẽos
"(Concerning) my monument: (it

is) of Mousaios, the son of Nadys."

\section{Comments}

The inscription runs in left-to-right direction of writing over three lines, and uses for the distinction of individual units punctuation in the form of two dots in columnar arrangement (:).

miém: $\mathrm{A}(\mathrm{m} / \mathrm{f}) \mathrm{sg}$. in $-m$ of the possessive pronoun of the 1 st person singular mie- "my", corresponding to Luwian hieroglyphic (a)miof the same function (see discussion of C.Ha 1 above).

mñémam: $\mathrm{A}(\mathrm{m} / \mathrm{f}) \mathrm{sg}$. in - $m$ of the noun mñéma- "stele, memorial", which, as we have seen in the discussion of C.Kr 1 above, is a patent loan from Greek $\tau$ ó $\mu v \tilde{\eta} \mu \alpha$ "memorial, memory". Note that we have here an instance of the accusativus respectus.

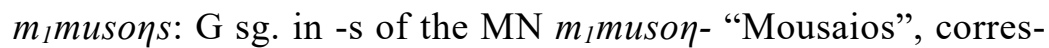

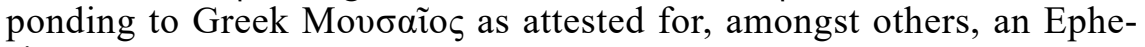
sian.

nads: G sg. in $-s$ of the MN nad- "Nadys", attested in form of N $\alpha \delta v \varsigma$ for Asia Minor. ${ }^{70}$ In view of its association with the following nẽos "son" (see section 3 above), this $\mathrm{MN}$ functions as a patronymic.

\section{C.Ka 3 inscription above the entrance of a rock-cut chamber tomb, dated to before the middle of the 4 th century $\mathrm{BC}^{71}$}

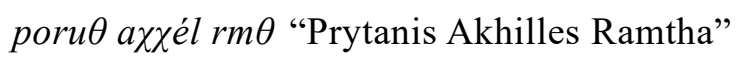

\section{Comments}

The inscription runs in left-to-right direction of writing over two lines in scriptio continua. As to the reading of the signs, the first one in line 1 is identified by Franz Steinherr as $p i .^{72}$ Furthermore, we owe it to the merit of Adiego that, on the basis of the photo by Frei \& Marek, the $3 \mathrm{rd}$ sign of line 1 and 6 th sign of line 2 are identified as the

\footnotetext{
${ }^{69}$ Masson, Un nouveau fragment, 123-131; Adiego, The Carian Language, 151.

${ }^{70}$ Adiego, The Carian Language, 461.

${ }^{71}$ Roos, The Rochtombs of Caunus, 42; 93; P1. 40.

${ }^{72}$ Roos, The Rochtombs of Caunus, 93, note 3 (on page 109).
} 
wau-like Carian rho. ${ }^{73}$ However, it should be realized that the circle with horizontal bar is not the primary sibilant but a variant of theta normally written with a cross inside, whereas the fifth letter in line 2, changed by Adiego in the variant of $p i$ also attested for the Espanca alphabet, positively consists of lambda ${ }^{74}$

poru $\theta$ : endingless $\mathrm{N}(\mathrm{m} / \mathrm{f}) \mathrm{sg}$. of the titular expression poru $\theta$-, corresponding to Greek $\pi \rho v ́ \tau \alpha v i \varsigma$.

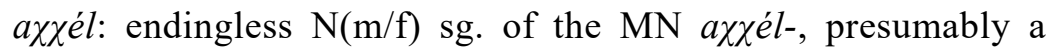
reflex of Greek A $\chi \imath \lambda(\lambda) \varepsilon v ́ \varsigma$.

$r m \theta$ : endingless $\mathrm{N}(\mathrm{m} / \mathrm{f}) \mathrm{sg}$. of the family name $\operatorname{rm} \theta$ - "Ramtha".

\section{E.Sa 1 reliquary for three mummified reptiles from Sais, ${ }^{75}$ presumably dating to the 7 th century $\mathrm{BC}^{76}$}

darqpéon:vén ${ }_{1} i \quad m<o>$ ñ̃a qẽe?]noiñoẽ:qunẽ

Jtm ntr ' 3 dj 'nh snb $\check{S} 3$ rkbym
"Tarkupiamos has made (this) memorial for (his) wife Qe[?]noinoa." "Atum the great god may give life and health to Tarkupiamos!"

\section{Comments}

The Carian part of this inscription runs in retrograde direction of writing and is divided over two lines, the first apparently being broken off, though it is not clear whether or how much letters are missing. Units within the text are marked by punctuation in the form of two dots in columnar arrangement (:).

darqpéon: endingless $\mathrm{N}(\mathrm{m} / \mathrm{f}) \mathrm{sg}$. of the $\mathrm{MN}$ darqpéon "Tarkupiamos". This name is represented in Egyptian hieroglyphic by $\check{S} 3 \mathrm{rkbym}$, but it should be realized that the distinction between dentals and sibilants with respect to foreign names in Egyptian hieroglyphic is notoriously distorted. To this comes that Tarkupiamos is a personal name of a familiar Luwian type (GN + participle of the middle-passive in - $m$ of the verb piya- "to give"). ${ }^{77}$

vén ${ }_{1} i$ : endingless $\mathrm{A}(\mathrm{n}) \mathrm{sg}$. of the noun vén ${ }_{1} i^{-}$"memorial", corresponding to Luwian hieroglyphic wana- "altar; stele" and Lydian vãna"grave". 78

${ }^{73}$ Adiego, The Carian Language, 152 (modified drawing); cf. photo in Frei \& Marek, Neues zu den karischen Inschriften, 126 (note, however, that 6th sign of line 2 is in the shadow and that the 3rd sign of line 1 may well be a normal rho).

${ }^{74}$ So already Best, Zur Herkunft des Diskos, 49.

${ }^{75}$ Adiego, The Carian Language, 32-33. For the Carian inscriptions from Egypt in general, cf. Masson \& Yoyotte, Objects pharaoniques and Masson, Carian Inscriptions.

${ }^{76} \mathrm{Cf}$. Adiego, The Carian Language, 31 on another inscription from Sais, E.Sa 2.

${ }^{77}$ Houwink ten Cate, The Luwian Population Groups, 176-177.

${ }^{78}$ Gusmani, Lydisches Wörterbuch, 222; cf. Woudhuizen, Selected Luwian Hieroglyphic Texts, 430. 
$m<o>n \tilde{n} a \chi o$ : 3 rd person sg. of the past tense in $-\chi o$ of the verb $m<o>n \tilde{n} a-$ "to make". Note that the given emendation is ascertained by the occurrence of this verbal form in C.xx 2 (see discussion above).

$q \tilde{e}[?]$ noiñoẽ: endingless $\mathrm{D}$ sg. (or do we have to assume a iota

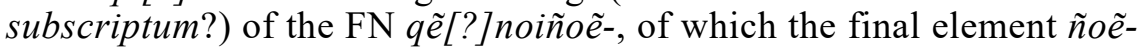
recalls the one in Graeco-Egyptian female names like Arsinoe of the Hellenistic period.

qunẽ: endingless $\mathrm{D}$ sg. (or do we have to assume a iota subscriptum?) of the noun qunẽ- "wife", corresponding to Greek yvví of the same meaning.

\section{E.Me 16 stele from Memphis ${ }^{79}$}

éroe/péqras-té mones/nẽos

necoẽs-té
"(Of) Heroe, and of Pigras, the son of Manes, and of Nekho."

\section{Comments}

The inscription runs in retrograde direction of writing and is divided over three lines. Units are distinguished by punctuation in the form of a vertical bar (/). The recurrent elements -té "and" and nẽos have been discussed in section 3 above. What remains are 4 personal names, 3 of which show the expected G sg. in $-s$. Of the names, the first, éroe "Heroe", is female in nature. The second, péqras "Pigras" recalls the name of a Carian advisor of the Egyptian pharaoh Psamme-

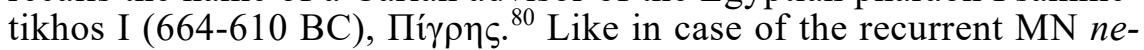
coẽ- "Nekho" (see section 3 above), we are probably dealing here with a Carian named after this pharaoh than this historical figure himself (which would allow us to date the inscription to the 7th century $\mathrm{BC}$, but the Carians are settled in Memphis only later on, in the reign of Amasis [568-526 BC]). ${ }^{81}$ The MN mone- "Manes", finally, we are already familiar with in writing variant $m n \tilde{n}$ - from C.Ha 1 (see discussion in section 4.1 above).

\section{E.Me 17 stele from Memphis ${ }^{82}$}

darẽaés um ${ }_{10}$ /

$\theta u \theta$ s pons-té nc-aqẽ
"I (am) of Dareias."

"Thuthos and Bonos have made."

\footnotetext{
${ }^{79}$ Adiego, The Carian Language, 48.

80 Vittmann, Ägypten und die Fremden, 155 and 175; cf. Adiego, The Carian Language, 31.

${ }^{81}$ Adiego, The Carian Language, 2.

${ }^{82}$ Adiego, The Carian Language, 48-49.
} 


\section{Comments}

The inscription runs in retrograde direction of writing and is divided over four lines. Units are distinguished by a punctuation mark in the form of a vertical bar (/). Owing to the recurrent element $u m_{1} O$ "I", the inscription can be classified to the group of "redende Inschriften" (see section 3 above). The monument is of darẽaés "Dareias", a Persian name, which is regularly marked by the G sg. in $-s$. It is set up by $\theta u \theta s$ "Thuthos" (cf. Egyptian Thoth) and pons "Bonos", which both render the $\mathrm{N}(\mathrm{m} / \mathrm{f}) \mathrm{sg}$. in $-s$. This analysis is further underlined by the sequence $n c-a q \tilde{e}$, which consists of the introductory particle $n c$, corresponding to Lydian $n a k$ for the same function, ${ }^{83}$ and the verbal form aqe , the 3rd person of in this case clearly the plural of the past tense

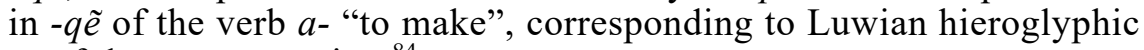
$a$ - of the same meaning. ${ }^{84}$

\section{E.Me 18 stele from Memphis ${ }^{85}$}

qadulís quarés car/soẽ

éé $\theta$ aus $m_{1}<\tilde{e} e \tilde{e}-o r>q \tilde{e}$ um $m_{1}$

écnuoẽs-té/ncarẽ-té

\author{
"Of Kandaules (and) Khuares, (...)." \\ "Eethaus has d(edicat)ed me as a \\ thank-offering." \\ "And of Ekhnuoes and (of) Nkhares."
}

\section{Comments}

The inscription runs in retrograde direction of writing, and is divided over eight lines. Units are distinguished by the punctuation in form of a vertcial bar (/). The final section of the inscription, lines 6-8, is in a different type of lettering and clearly added later. In sum, there can be distinguished three sections, presenting the names of: (1) the original owners of the monument, (2) the dedicator of the monument, and (3) the secondarily added owners of the monument.

The middle section with the dedicatory part belongs to the class of "redende Inschriften" owing to the use of the pronoun $u m_{l} e$ " "me". The sequence $m_{1} q \tilde{e}$ is marked by the ending of the 3rd person sg. of the past tense, $-q \tilde{e}$, but likely confronts us with an abbreviation of the noun indicating the nature of the dedication and the verb. On the basis of the parallels from the inscriptions from Caria, $m_{l}$ likely represents $m_{l} \tilde{e} \tilde{e}$, the abbreviation of meluwe- "thank-offering" and the verbal root likely consist of or- "to dedicate" (see discussion of C.xx 1 and C.Ha 1 in section 4.1 above). Note finally that qadulis confronts us with a

\footnotetext{
${ }^{83}$ Gusmani, Lydisches Wörterbuch, 169.

${ }^{84}$ Woudhuizen, Selected Luwian Hieroglyphic Texts, 137 and 319.

${ }^{85}$ Adiego, The Carian Language, 49-50.
} 
patent Luwian $\mathrm{MN}$ as it corresponds to Lydian $\operatorname{K} \alpha \nu \delta \alpha v \lambda \eta \varsigma^{86}{ }^{86}$ derived from the Luwian hieroglyphic titulary expression hantawat- "king". ${ }^{87}$

\title{
E.Me 30 false-door stele from Memphis ${ }^{88}$
}

darusoz mlzoOs-té:sușzés "Of Darusos and (of) Mesothes from Susa."

\section{Comments}

The inscription runs in retrograde direction of writing, and is divided over two lines. Units are distinguished by a punctuation mark in the form of two dots in columnar arrangement (:). The legend consists of a possession formula, and the two MNs as wel as the specification of their hometown are consistently rendered in the G sg. in $-s$ or $-z$. The MNs are clearly of Persian nature,${ }^{89}$ and this observation is underlined by the fact that their hometown is specified by suscé-, an ethnic in -zé- (cf. Luwian hieroglyphic $-z \bar{a}$ - and Lycian $-z i-)^{90}$ of the TN $\breve{S} u s ̌ a-$ "Susa" ${ }^{91}$ Accordingly, the inscription likely dates from the period of Persian rule over Egypt, which begins with the conquest by Kambyses in $525 \mathrm{BC}$ and ends with the conquest by Alexander the Great in 332 BC. ${ }^{92}$

\section{E.Me 36 false-door stele from Memphis ${ }^{93}$}

\author{
em 1 o/diorstș/ \\ sunmqe/Oarm ${ }_{1}$ més \\ "I (am) of Deiorestes, \\ companion of Tharmes."
}

\section{Comments}

The inscription starts in retrograde direction of writing, but continues from sunmqe onwards in left-to-right direction of writing. Units in the text are distinguished by a punctuation in the form of a vertical bar (/). The possession-formula follows the pattern of E.Me 17 (see discussion above). New is that the owner, Deiorestes, whose name may be a reflex of Avestan Dáraiiat.ra $a,{ }^{94}$ is specified by the entry

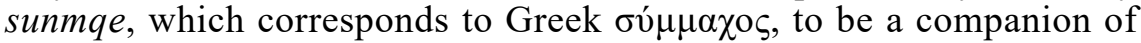
a certain Tharmes.

${ }^{86}$ Gusmani, Lydisches Wörterbuch, 274.

${ }^{87}$ Woudhuizen, Selected Luwian Hieroglyphic Texts, 425.

${ }^{88}$ Adiego, The Carian Language, 58.

${ }^{89}$ For the first MN, see RlA, s.v. Dârejawôš (= Greek Dareios), esp. the variants Dari'ušš $u$ and Daruešš $u$. For the second MN, compare Greek Masistēs, a reflex of Old Persian matišta- "größter, oberster", see Mayrhofer, Iranisches Personennamenbuch, 61, 220.

${ }^{90}$ Woudhuizen, Selected Luwian Hieroglyphic Texts, 431.

${ }^{91}$ Valat, Répertoire Géographique, s.v. Š uša(n), etc.

92 Vittmann, Ägypten und die Fremden, 120 and 141.

${ }^{93}$ Adiego, The Carian Language, 62.

${ }^{94}$ Mayerhofer, Iranisches Personennamenbuch, 35, no. 102. 


\begin{tabular}{|c|c|c|}
\hline \multicolumn{3}{|c|}{ Noun } \\
\hline & sg. & pl. \\
\hline $\mathrm{N}(\mathrm{m} / \mathrm{f})$ & $-S / s / s+,-$ & \\
\hline $\mathrm{A}(\mathrm{m} / \mathrm{f})$ & $-m,-n / \tilde{n},-$ & \\
\hline N-A (n) & - & \\
\hline $\mathrm{D}$ & $-a,-(=-i ?)$ & \\
\hline $\mathrm{G}$ & $-S / z$ & \\
\hline \multicolumn{3}{|c|}{ Pronoun } \\
\hline & $1 \mathrm{st}$ sg. & 2 nd sg. \\
\hline $\mathrm{N}$ & $u m_{1} O, \mathrm{em}_{1} \mathrm{O}$ & \\
\hline A & $u m_{1} \dot{e}, m_{1}(i), m e ́$ & \\
\hline \multicolumn{3}{|c|}{ Verb } \\
\hline & active & middle-passive \\
\hline past tense 3 rd pers. sg. & $-\chi o,-(q) q \tilde{e}$ & \\
\hline 3rd pers. pl. & $-q \tilde{e}$ & \\
\hline infinitive & $-u \tilde{n} o$ & \\
\hline
\end{tabular}

Table I. Grammatical overview.

\begin{tabular}{|c|c|c|c|}
\hline Carian & Greek & Carian & Greek \\
\hline éqro- & 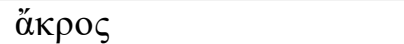 & $q l q$ & $\dot{\eta} \kappa \hat{\lambda} \lambda_{1} \xi$ \\
\hline$\theta$ opo $<l o>n u$ & $\tau \mathrm{o} \pi \mathrm{o} \lambda \mathrm{ovl}=\tau \mathrm{ol} \mathrm{A} \pi \mathrm{o} \mathrm{\nu} \lambda \mathrm{ov} \mathrm{l}$ & quпе̃ & $\dot{\eta} \gamma v \vee \eta ́$ \\
\hline í̃orẽ- & $\tau o ́$ i $\varepsilon \rho \varepsilon i ̃ o v$ & sșam & 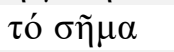 \\
\hline mñema- & $\tau$ ${ }^{\prime} \mu \nu \tilde{\eta} \mu \alpha$ & sunmqe & 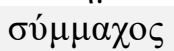 \\
\hline nẽos & véos & zoí & ұớ \\
\hline orda- & ỏp$\theta$ ó $\varsigma$ & $-(q) q \tilde{e},-\chi o$ & $-\kappa \varepsilon$ \\
\hline poru $\theta$ & $\dot{\alpha} \pi \rho v ́ \tau \alpha v i \varsigma$ & $-t e ́$ & $\tau \varepsilon$ \\
\hline
\end{tabular}

Table II. Overview of the relationship of Carian with Greek. 


\section{BIBLIOGRAPHY}

Adiego, Ignacio J. The Carian Language, with an appendix by Koray Konuk. Handbook of Oriental Studies, Section One: The Near and Middle East 68, LeidenBoston, 2007.

Beekes, Robert S.P. Vergelijkende taalwetenschap, Tussen Sanskrit en Nederlands, Utrecht, 1990.

Best, Jan G.P. "Zur Herkunft des Diskos von Phaistos." Supplementum Epigraphicum Mediterraneum ad Talanta, Proceedings of the Dutch Archaeological and Historical Society 13, 1981 [1982], pp. 49-56.

Bryce, Trevor. The Kingdom of the Hittites. Oxford (New Edition), 2010.

Frei, P., \& Marek, C. "Neues zu den karischen Inschriften von Kaunos." Kadmos 39, 2000, pp. 83-132.

Friedrich, Johannes. Kurzgefaßtes Hethitisches Wörterbuch. Heidelberg, 1991.

Gusmani, Roberto. Lydisches Wörterbuch, Mit grammatischer Skizze und Inschriftsammlung. Heidelberg, 1964.

Gusmani, Roberto. "Isoglossi lessicali Greco-Ittite." Studi linguistici in onore di Vittore Pisani, Vol. 1, Brescia, 1969, pp. 503-514.

Gusmani, Roberto. "Zwei neue Gefässinschriften in karischer Sprache.” Kadmos 17, 1978, pp. 67-75, Tafels I-IV.

Gusmani, Roberto. “Karische Beiträge.” Kadmos 27.2, 1988, pp. 139-149.

Houwink ten Cate, Philo H.J. The Luwian Population Groups of Lycia and Cilicia Aspera during the Hellenistic Period. Leiden, 1961 (dissertation).

Hoz, J. de. "The Phoenician Origin of the Early Hispanic Script." In: Baurain, C., Bonnet, C., \& Krings, V., (éds.), Phoinikeia Grammata, Lire et écrire en Mediterranée. Actes du Colloque de Liège, 15-18 novembre 1989, Namur, 1991, pp. 669-682.

Jeffery, Lilian H. The Local Scripts of Archaic Greece, A study of the origin of the Greek alphabet and its development from the eighth to the fifth centuries B.C. Oxford (Revised edition with a supplement by A.W. Johnston), 1990.

Jucker, H., \& Meier-Brügger, M. "Eine Bronzephiale mit karischer Inschrift." Museum Helveticum 35, 1978, pp. 104-115.

Mallory, J.P., \& Adams, D.Q. The Oxford Introduction to Proto-Indo-European and the Proto-Indo-European World. Oxford (Reprinted), 2007.

Masson, Olivier. "Un nouveau fragment d'inscription carienne de Kaunos." Anadolu 17, 1973 [1975], pp 123-131, Planches I-II.

Masson, Olivier. "Un lion de bronze de provenance égyptienne avec inscription carienne." Kadmos 15.1, 1976, pp. 80-83.

Masson, Olivier. "Notes d'épigraphie carienne III-IV.” Kadmos 16, 1977, pp. 87-94.

Masson, Olivier. Carian Inscriptions from North Saqqâra and Buhen. Egypt Exploration Society, London, 1978.

Masson, Olivier. Les inscriptions chypriotes syllabiques: recueil critique et commenté. Études Chypriotes 1, Paris, 1983.

Masson, O., \& Yoyotte, J. Objets pharaoniques à inscription carienne. Le Caire, 1956.

Mayrhofer, Manfred. Iranisches Personennamenbuch, Band I: Die altiranischen Namen. Wien, 1979.

Melchert, H. Craig. "Some remarks on new readings in Carian." Kadmos 32.2, 1993, pp. 77-86.

Melchert, H. Craig. A Dictionary of the Lycian Language. Ann Arbor-New York, 2004. 
R1A Reallexikon der Assyriologie.

Roos, Pavo. The Rock-Tombs of Caunus, 1 The Architecture. Studies in Mediterranean Archaeology 34:1, Göteborg, 1972.

Vallat, François. Répertoire Géographique des Textes Cunéiformes, Band 11: Les noms gégraphiques des sources suso-élamites. Beihefte zum Tübinger Atlas des vorderen Orients, Reihe B (Geisteswissenschaften Nr. 7/11), Wiesbaden, 1993.

Ventris, Michael, \& Chadwick, John. Documents in Mycenaean Greek, With a foreword by the late Alan J. B. Wace. Cambridge (second edition by John Chadwick), 1973.

Vittmann, Günter. Ägypten und die Fremden im ersten vorchristlichen Jahrtausend. Kulturgeschichte der Antiken Welt 97, Mainz am Rhein, 2003.

Waanders, Frits, \& Woudhuizen, Fred C. "Phrygian \& Greek." Talanta, Proceedings of the Dutch Archaeological and Historical Society 40-41, 2008-9, pp. 181217.

Woudhuizen, Fred C. "Etruscan Origins: The Epigraphic Evidence." Talanta, Proceedings of the Dutch Archaeological and Historical Society 14-15, 1982-3, pp. 91-117.

Woudhuizen, Fred C. "Lydian: Separated from Luwian by three signs." Talanta, Proceedings of the Dutch Archaeological and Historical Society 16-17, 1984-5, pp. 91-113.

Woudhuizen, Fred C. "Origins of the Sidetic Script. Talanta, Proceedings of the Dutch Archaeological and Historical Society 16-17, 1984-5, pp. 115-127.

Woudhuizen, Fred C. The Language of the Sea Peoples, With a Foreword by Jan Best. Publications of the Henri Frankfort Foundation 12, Amsterdam, 1992.

Woudhuizen, Fred C. "The Transmission of the Phoenician Alphabet in the Mediterranean Region." Rivista di Studi Fenici 34.2, 2006 [2009], pp. 173-184.

Woudhuizen, Fred C. "Two Notes on Lydian." Talanta, Proceedings of the Dutch Archaeological and Historical Society 42-43, 2010-1, pp. 207-213.

Woudhuizen, Fred C. Selected Luwian Hieroglyphic Texts, The Extended Version. Innsbrucker Beiträge zur Sprachwissenschaft 141, Innsbruck, 2011.

Woudhuizen, Fred C. "Lycian Forms of the Enclitic Pronoun of the $3^{\text {rd }}$ Person: An Overview of the Relevant Data." Colloquium Anatolicum 11, 2012, pp. 415436.

Yakubovich, Ilya. Sociolinguistics of the Luvian Language. Brill's Studies in IndoEuropean Languages \& Linguistics 2, Leiden-Boston, 2010. 